\title{
Strategies to Optimize Adult Stem Cell Therapy for Tissue Regeneration
}

\author{
Shan Liu ${ }^{1,2,3,+}$, Jingli Zhou 1,2,3,+, Xuan Zhang ${ }^{1,2,3}$, Yang Liu 1,2,3, Jin Chen ${ }^{1,2,3}$, Bo Hu ${ }^{1,2,3}$, \\ Jinlin Song ${ }^{1,2,3, *}$ and Yuanyuan Zhang ${ }^{4, *}$ \\ 1 Chongqing Key Laboratory for Oral Diseases and Biomedical Sciences, Chongqing 401147, China; \\ 15823106296@163.com (S.L.); journeyzone@163.com (J.Z.); 13677691923@163.com (X.Z.); \\ 13657638643@163.com (Y.L.); ChenJindentistry@163.com (J.C.); huboisthebest@sina.com (B.H.) \\ 2 College of Stomatology, Chongqing Medical University, Chongqing 401147, China \\ 3 Chongqing Municipal Key Laboratory of Oral Biomedical Engineering of Higher Education, \\ Chongqing 401147, China \\ 4 Wake Forest Institute for Regenerative Medicine, Wake Forest School of Medicine, Medical Center Blvd. \\ Winston-Salem, NC 27157, USA \\ * Correspondence: soongj1@163.com (J.S.); yzhang@wakehealth.edu (Y.Z.); Tel.: +86-23-8886-0026 (J.S.); \\ +1-336-713-1189 (Y.Z.); Fax: +86-23-8886-0222 (J.S.); +1-336-713-7290 (Y.Z.) \\ + These authors contributed equally to this study and share first authorship. \\ Academic Editor: Wenbin Deng \\ Received: 7 April 2016; Accepted: 10 May 2016; Published: 21 June 2016
}

\begin{abstract}
Stem cell therapy aims to replace damaged or aged cells with healthy functioning cells in congenital defects, tissue injuries, autoimmune disorders, and neurogenic degenerative diseases. Among various types of stem cells, adult stem cells (i.e., tissue-specific stem cells) commit to becoming the functional cells from their tissue of origin. These cells are the most commonly used in cell-based therapy since they do not confer risk of teratomas, do not require fetal stem cell maneuvers and thus are free of ethical concerns, and they confer low immunogenicity (even if allogenous). The goal of this review is to summarize the current state of the art and advances in using stem cell therapy for tissue repair in solid organs. Here we address key factors in cell preparation, such as the source of adult stem cells, optimal cell types for implantation (universal mesenchymal stem cells $v s$. tissue-specific stem cells, or induced $v$ s. non-induced stem cells), early or late passages of stem cells, stem cells with endogenous or exogenous growth factors, preconditioning of stem cells (hypoxia, growth factors, or conditioned medium), using various controlled release systems to deliver growth factors with hydrogels or microspheres to provide apposite interactions of stem cells and their niche. We also review several approaches of cell delivery that affect the outcomes of cell therapy, including the appropriate routes of cell administration (systemic, intravenous, or intraperitoneal $v s$. local administration), timing for cell therapy (immediate $v s$. a few days after injury), single injection of a large number of cells $v s$. multiple smaller injections, a single site for injection vs. multiple sites and use of rodents $v s$. larger animal models. Future directions of stem cell-based therapies are also discussed to guide potential clinical applications.
\end{abstract}

Keywords: stem cells; stem cell therapy; optimizing strategy; tissue repair; tissue regeneration

\section{Introduction}

Currently, adult stem cells are the primary source of cells studied in tissue regeneration. These cells are most from hematopoietic, mesenchymal, epithelial and neural cell lineages. As the most commonly used source in cell therapy, mesenchymal stem cells (MSCs) possess high proliferation ability, paracrine effect, multipotent differentiation potential immunomodulatory capacity [1,2], and profiles of cell surface markers [3]. Furthermore, MSCs can home to tumors carrying with anticancer agents and 
have an important role in the resistance to various anti-cancer drugs. Table 1 summarizes key therapeutic properties of MSCs for use in tissue regeneration therapy. MSCs are potential in the treatment of various congenital defects (i.e., congenital heart disease [4], congenital diaphragmatic hernia [5], myelomeningocele [6]), trauma or ischemia injuries (i.e., myocardial ischemia [7], spinal injury [8], kidney failure [9]), immune disorders (diabetes [10], arthritis [11], multiple sclerosis [12]) and degenerated diseases (i.e., intervertebral disc degeneration [13], muscle degeneration [14], sensorineural hearing loss [15]). However, a major difficulty with stem cell therapy is to maintain cell viability, properties and function of stem cell before and after implantation in vivo. Once stem cells are isolated from the native tissue environment, they quickly lose the niche and function they had when growing in culture dishes. In addition, they shorten cell lifespan because of over-expansion in vitro. Furthermore, cellular DNA tends to be instable during long-term culture. Such cells implanted in the host lead low rates of cell survival, and poor outcomes in-growth, homing, differentiation and paracrine effects. On the other hand, the environment of implanted site, such as blood supply, the collagen density of tissue (scaring tissue formation) and the numbers of existing endogenous stem cells, greatly affects the fate of grafted cells and the effect of cell-therapy. Clearly, longer the graft cells survive in the appropriate environments provided, the more trophic factors secreted, and better tissue regeneration induced. Thus, extension of transplanted cell life-span and stimulation of activity of paracrine effects can improve the tissue repair. Therefore, it is essential to optimize the strategies for stem cell therapy for tissue regeneration in solid organs. In this review, several general concepts and strategies have been addressed for cell therapy, which could be specifically justified when applied in different tissues or organs.

Table 1. Overview of key therapeutic properties of mesenchymal stem cells in different disorders.

\begin{tabular}{cl}
\hline Types of Disorders & \multicolumn{1}{c}{ Key Therapeutic Properties of Stem Cells } \\
\hline $\begin{array}{c}\text { Congenital defects } \\
\text { Trauma or injury }\end{array}$ & $\begin{array}{l}\text { Pluripotency or able to differentiate into multiple cell types; Enables maintenance } \\
\text { of an undifferentiated phenotype in multiple subcultures; Capacity for self-renewal }\end{array}$ \\
\hline \multirow{2}{\text{Immunedisorders}}{} & $\begin{array}{l}\text { Immunomodulatory effects or reduce local inflammation and fibrosis formation; } \\
\text { Counteract chemotactic signals released to recruit immune cells to the site of injury; } \\
\text { Paracrine effects, immune tolerance or blunt host immune response }\end{array}$ \\
\hline Degenerated diseases & $\begin{array}{l}\text { Neruoprotection; Anti-apoptosis; Anti-aging effects; Stimulate endogenous tissue } \\
\text { regeneration potential }\end{array}$ \\
\hline
\end{tabular}

\section{Sources of MSCs}

MSCs were initially recognized in bone marrow and afterward revealed in many other organs and tissues. These adult stem cells appear to have a pericytic or fibroblastic origin from various tissue environments. Recently, more evidences have indicated that MSCs exist nearly in any vascularized tissues in vivo [16]. However, a large difference in their expression is noted in various sources of MSCs. While bone marrow [17] is the broadly identified source of adult stem cells, alternative sources of MSC-like cells has been gradually recognized, including adipose tissue [18], dental pulp [19], synovial membrane [20], periodontal ligament [21], hair follicle [22], endometrium [23], placenta [24], umbilical cord [25], peripheral blood [26], umbilical cord blood [27], amniotic fluid [28], menstrual blood [29], milk [30] and urine [31]. Although the precise identity of these stem cells in vivo is not well defined, a number of surface antigens, instead of a single molecule, have been widely used in characterization of MSCs in vitro. These surface markers may be associated to their stemness, such as expression of CD10, CD13, CD29, CD44, CD73, CD90, CD105, CD146, CD271, Stro-1 and SSEA-4, low/negative expression of CD14 (CD11b), CD19 (or CD79a), CD34, CD45 and HLA-DR [32-38].

Among different types of MSCs, they possess similar multipotential differentiation potential although their differentiation efficacy varies during specific lineage differentiation for tissue regeneration [39]. It appears that adult stem cells favorably repair the tissue where they originated from. 
The heterogeneity (i.e., proteonomic [40], transcriptonomic [41], epigenomic [42]) and secretomes [43] of adult stem cells from different tissues may account for the lineage-specific differentiation along with their resident tissue. Recent studies have shown that tissue-specific stem cells retained superiority in lineage-specific differentiation, along with their resident tissue origins and natural roles [43]. For example, adipose-derived stem cells (ADSCs) have a significant upregulation of adipogenic genes while bone marrow-derived stem cells (BMSCs) express higher magnitude of osteogenic genes after in vitro induction [44].

\section{Optimal Cell Source for Cell Therapy}

\subsection{Combinations of Somatic and Stem Cells}

Cell-cell interactions are important roles in cell proliferation and differentiation of MSCs. Combinations of annulus fibrosus cells with BMSCs enhanced somatic cell proliferation and extracellular matrix synthesis [45]. When stem cells were co-implanted with somatic functional cells, cell number of both cell types increased and promoted tissue regeneration in vivo [46].

\subsection{Primary Cultured Cells vs. Cell Lines}

As grafted cell sources, primary cultured autologous or allograft cells as the graft sources are commonly used for tissue repair because their biologic characteristics are stable. However, with primary cultured cells, the number of cell passages is finite. In contrast, immortalized cell lines can generate a large quantity of cells via many passages. However, the cell lines are rarely used in tissue regeneration research because of the high risk of tumor formation. In addition, cell lines usually lose their initial cell morphology and differentiation capacity with increasing passages, causing weak regeneration capability after cells are implanted in vivo [47] and abnormal alterations of cell DNA, RNA, and proteins over time during long-term culture [48].

\subsection{Passages of Stem Cells Used for Implantation}

One report indicated no significant differences in differentiation into osteogenic, adipogenic and chondrogenic tissue among tonsil-derived MSCs from passages 2 to 15, with proliferative ability decreasing after passage 15 [49]. In another report, human umbilical cord-derived MSCs in passage 30 could still affect hematopoiesis [50]. However, other studies demonstrated that favorable passage of stem cells in chondrogenic differentiation is at passage 4 , which develops potential of cartilage-like tissue in MSCs [51]. In long-term passage culture studies, BMSCs decreased bone formation and increased osteogenic disorders at passage 12 [52]. Therefore, no more than 5 passages of MSCs appear to be optimal for cell growth, paracrine effects, differentiation capacity, and DNA stability in cultures [48].

\subsection{Non-Induced Differentiation of Stem Cells vs. Induced Differentiation of Stem Cells in Tissue Repair}

It often takes over several weeks to culture and induce stem cells in vitro, i.e., 4-6 weeks for cell culture and expanding to gain enough cells for implantation, and then $2-4$ weeks to induce cell differentiation at the terminal stages. Such cell manipulation remarkably decreases cell viability and regeneration capacity after these cells are implanted in vivo [53]. Thus, for in vivo studies, it seems more advantageous to use non-induced stem cells than induced stem cells (see Table 2). 
Table 2. Comparison of non-induced and induced differentiation of stem cells in tissue repair in vivo.

\begin{tabular}{ccc}
\hline Comparison Items & Induced Differentiation of Stem Cells & Non-Induced Differentiation of Stem Cells \\
\hline Differentiation status & Differentiated & Non-differentiated \\
In vitro manipulation & More cell expansion and & Less \\
Cell viability in vivo & in vitro differentiation & Higher \\
Lifespan in vivo & Moderate & Longer \\
Secretion of trophic factors & Shorter & More \\
Recruitment of resident cells & Moderate & More \\
Corporation with resident cells & Moderate & Cell fusion, differentiation, and stimulation \\
Effect on tissue repair in vivo & Limitation due to short cell life-span & Acceleration to guide local stem cells differentiation \\
\hline
\end{tabular}

In the last decade, Takahashi and Yamanaka first reprogrammed induced pluripotent stem cells (iPSCs) from somatic cells using different transcription factors [54]. The main characteristic of iPSCs have pluripotency and can replace the use of embryonic stem cells (ESC) because they possess the ability to self-renew and differentiate to three germ layers and all cell types [55]. Thus, use of iPSCs avoids ethical issues concerning the depletion of embryos in research and clinics consequently [54]. iPSCs provide great opportunities for regenerative medicine, disease modeling, and drug discovery [55]. However, several major disadvantages obstruct the application, namely, genomic modification, teratogenicity, transmission of nonhuman pathogens to humans, and cost and labor of reprogramming process [56]. Although recent advances in reprogramming footprint-free and xeno-free iPSCs made iPSCs become the most appealing but it is necessary to significantly improve reprogramming technology to overcome the limitations.

\section{Controlled-Release Exogenous Growth Factors}

One of the effective and controllable methods to apply growth factors that can augment stem cell treatments is genetic manipulation of the cells overexpressing diverse growth factors before implantation $[57,58]$. The genes are often introduced into the cells via non-viral or viral techniques; the former approaches are safer, but they have low transfection efficiency and typically do not result in integration of the transgene. Common viral vectors used in the previous gene therapy studies are retroviruses such as Moloney murine leukemia virus, a serotype 5 adenovirus, adeno-associated viruses, or lentiviruses [59]. Using stem cells from fat or urine transfected with vascular endothelial growth factor (VEGF) to deliver bioactive angiogenic growth factors caused endothelial cell migration and proliferation in vivo [60], and promoted endothelial and smooth muscle cell function recovery, increased processing of oxidation within cavernous tissue, and improved erectile dysfunction in a rat model of diabetic erectile dysfunct [61]. In addition, adult neural stem cells infected with bicistronic lentiviral vector Lv.IL-10, encoding both inerleukin-10 and green fluorescent protein GFP driven by a cytomegalovirus promoter to express interleukin-10 enhanced immune suppression, remyelination, and neuronal repair [62]. However, the long-term safety of doses of released growth factors and the risk of tumor-genesis by genetically modified stem cells with viral transfection are concerns [63].

Most growth factors have half-lives within minutes, emphasizing the importance of controlled, continuous release within a protective delivery vehicle [64]. Direct injections of growth factors were less effective in promoting tissue healing due to their rapid dilution and short half-lives. These bioactive proteins were released homogeneously from the microspheres providing stem cell niches [65]. A key advantage of microspheres is the potential for minimally invasive local delivery, allowing for optimal construct-tissue integration [66]. Bioactive microspheres loaded with therapeutic growth factors provide controlled and sustained delivery to induce cell differentiation and stimulate tissue regeneration [67].

Microspheres derived from materials such as chitosan [68], alginate [69], lactic-co-glycolic acid (PLGA) [70], and chondroitin sulfate [71] have been used as carriers for coordinated release of growth factors. Co-encapsulation of microspheres with photopolymerizable $\mathrm{N}$-methacrylate glycol chitosan enhanced stem cell chondrogenesis in vitro [65] when a hydrogel matrix loaded with bone 
morphogenetic protein 6 and transforming growth factor- $\beta 3$ was co-administered with ADSCs. Urine-derived stem cells (USCs) combined with alginate micro-beans containing three groups of growth factors (insulin-like growth factor (IGF)-1 and hepatocyte growth factor (HGF) for muscle, VEGF and fibroblast growth factor (FGF)-1 for angiogenesis, and nerve growth factor (NGF) and IGF-1 for innervation) are superior in myogenesis, revascularization, and neurogenesis to those with one group of growth factors alone when subcutaneously implanted in vivo. In addition, PLGA microspheres in a hyaluronic acid scaffold promoted proliferation and migration of neural stem cells via release of brain-derived neurotrophic factors and VEGF. This approach also enhanced endothelial cell attachment on biomaterials in vitro, all of which could be beneficial in treating central nervous system injuries [70]. A stem cell transplantation system that contained autologous ADSCs and controlled-release NGF encapsulated within PLGA microspheres enhanced therapeutic efficacy of ADSCs delivered by periurethral co-injection in a rat model of stress urinary incontinence [72].

Several natural polymers employed as biologic scaffolds carry stem cells for tissue repair, including alginate, collagen, fibrin, albumin, hyaluronan, platelet-rich plasma, and gelatin [73]. Growth factors released from the scaffolds could significantly prompt stem cell growth and differentiation, but most of these proteins cannot bind with scaffolds and so require a bridge to covalently crosslink scaffolds on one end and bind growth factors on other end. Heparin, one such element, has high levels of sulfated anionic glycosaminoglycans that contain a growth factor binding domain [74] which allows heparin to bind growth factors with high affinity while retaining its biological activity [75]. Using heparin with growth factors controls their release keeps stem cells viable after transplantation [75]. A heparin-presenting injectable nano-fiber network bound and delivered paracrine factors that mimicked stem cell paracrine effects and promoted tissue healing in ischemic tissues [76]. In addition, transforming growth factor- $\beta 1$ (TGF- $\beta 1$ ) as a chondrogenic growth factor was coupled with a heparin domain to obtain TGF- $\beta 1$-conjugated F127 hydrogel, which induced chondrogenic differentiation of ADSCs in vivo [77].

\section{Preconditioning Stem Cells}

Preconditioning strategies in stem cell therapy increase cell survival rate and differentiation potential and enhance paracrine effects in suppressing inflammatory factors, immune responses, and fibrosis; these effects promote organ and tissue regeneration and functional recovery after cell implantation [78]. Generally, the harsh post-ischemic environment of injured tissue is associated with oxidative stress, chronic inflammation, fibrosis, extracellular matrix degradation, and immune rejection [79,80], which mediate apoptosis, poor cell survival, or low retention rate of the grafted cells [81]. Hence, prolonging stem cell survival and improving their therapeutic effects on regeneration in damaged tissues rely on prevention of anoikis, resistance against nutrient deprivation, elimination of immune rejection, and enhancement of anti-oxygen capability in the ischemic area. Three strategies are frequently involved in cell preconditioning: hypoxia, growth factors, and conditioned medium from functional cells or serum-free medium.

Hypoxia preconditioning pre-exposes cells to severe hypoxia to activate cellular defenses [81]. Hypoxia treatments vary from under $2 \%-5 \%$ oxygen and have enhanced cell viability [81] and proliferation of human MSCs [82]. In addition, hypoxia-preconditioned MSCs promoted angiogenesis and neurogenesis, and stimulated differentiation [83]. However, both adipogenic differentiation and chondrogenesis were inhibited when cells were exposed to hypoxia during differentiation [82].

Preconditioning of stem cells with growth factors like IGF-1 and VEGF enhance cytoprotective effects, resulting in improved efficiency of cell therapy [84,85]. IGF-1 is involved in the survival pathway [86] and has been widely used to enhance stem cell treatments $[87,88]$. In acute kidney injury models, preconditioning of MSCs with IGF-1 before infusion markedly improved cell migration, ameliorating renal structure damage and restoring normal renal function [88]. Similarly, cells with VEGF preconditioning also showed significant enhancement of cell proliferation, minimization of senescence, and better cell survival in a diabetes model [87]. Combining IGF-1 and FGF-2 better 
protected MSCs than VEGF alone [87]. MSCs-alginate constructs treated in vitro with TGF-1 for over 2 weeks [89] and transplanted under the dorsal skin of nude mice, generated new cartilage at 8 weeks after transplantation [89]. Before transplantation, 1 week of in vitro exposure to TGF-1 promotes new cartilage formation of human MSCs in alginate.

Conditioned medium from healthy functional cells can improve proliferation of multiple stem cell sources under varying structural environments [90]. MSCs isolated from diabetic animals enhanced survival, proliferation, angiogenic ability, and function of a diabetic heart when preconditioned with medium from healthy cardiomyocytes exposed to oxidative stress and high glucose [91]. VEGF levels increased in conditioned medium from neonatal rat cardiac myocytes treated with this approach, due to up-regulation of VEGF as a consequence of hypoxia [92]. Using a chondrogenic medium to precondition ADSCs effectively increased chondrogenic factor secretion (TGF- $\beta 2$, TGF- $\beta 3$, and IGF-1) and decreased angiogenic factor production (VEGF-A and FGF-2) [93] suggesting that conditioned medium from normal functional cells can guide the differentiation of stem cells. In vitro serum starvation (with or without VEGF) appears to favor cardioprotection, extracellular matrix remodeling and blood vessel maturation, all relevant for the late maturation phase in infarct healing [94].

\section{Routes of Cell Administration}

MSCs improve tissue repair mainly via differentiation and paracrine effects. Depending on therapeutic purposes, stem cells can be implanted in vivo via either systemic or local approaches (see Table 3). Systemic administration, including intravenous (iv), intraperitoneal (ip), and intraventricular injection, appears to mimic the route of endogenous MSCs via the circulatory system with final homing to the target sites. Local administration is designed to increase the number of implanted stem cells to the target sites for further cell fusion with the host cells or differentiation into the functional cells.

Table 3. Routes of stem cell implantation in solid organs in vivo.

\begin{tabular}{cccccc}
\hline Comparison Items & \multicolumn{2}{c}{ Systemic Administration } & \multicolumn{2}{c}{ Local Administration } \\
\cline { 2 - 6 } & $\begin{array}{c}\text { Intravenous } \\
\text { Injection (iv) }\end{array}$ & $\begin{array}{c}\text { Intra-Ventricular } \\
\text { Injection }\end{array}$ & $\begin{array}{c}\text { Intra-Peritoneal } \\
\text { Injection (ip) }\end{array}$ & $\begin{array}{c}\text { Intra-Organ } \\
\text { Injection }\end{array}$ & $\begin{array}{c}\text { Intra-Arterial } \\
\text { Injection }\end{array}$ \\
\hline $\begin{array}{c}\text { Ratio of implanted } \\
\text { cell retention or } \\
\text { Differentiation [95] }\end{array}$ & $1 \%$ & Up to 10\% & 0 & $10 \%-30 \%$ & $10 \%-20 \%$ \\
\hline Trophic effect & Yes & Yes & Yes (only) & Yes & Yes \\
\hline $\begin{array}{c}\text { Location of } \\
\text { implanted cell }\end{array}$ & $\begin{array}{c}\text { Lungs, Spleen, } \\
\text { Liver [95] }\end{array}$ & Blood circulation & $\begin{array}{c}\text { Omentum and } \\
\text { mesentery [96], } \\
\text { and most organs }\end{array}$ & $\begin{array}{c}\text { Targeted organ } \\
\text { or tissue }\end{array}$ & Targeted organ \\
\hline $\begin{array}{c}\text { Advantages of } \\
\text { procedures }\end{array}$ & Easy [97] & Mainly for Rodent & $\begin{array}{c}\text { Easy, particularly } \\
\text { for rodent [98] }\end{array}$ & $\begin{array}{c}\text { Immediate local } \\
\text { action [99] }\end{array}$ & $\begin{array}{c}\text { Applicable only } \\
\text { for patients or } \\
\text { large animals }\end{array}$ \\
\hline $\begin{array}{c}\text { Limitations or } \\
\text { complications }\end{array}$ & $\begin{array}{c}\text { target organ; most in } \\
\text { the lungs and } \\
\text { spleen [100] }\end{array}$ & $\begin{array}{l}10 \% \text { of the cells in } \\
\text { target organ [100] }\end{array}$ & $\begin{array}{c}\text { Might inject into } \\
\text { intestine, less } \\
\text { effect [101] }\end{array}$ & $\begin{array}{c}\text { An open surgery } \\
\text { is need to deliver } \\
\text { the majority of } \\
\text { cells in the right } \\
\text { sites [102] }\end{array}$ & $\begin{array}{c}\text { Interventional } \\
\text { therapy is } \\
\text { required } \\
\text { in large } \\
\text { animals [102] }\end{array}$ \\
\hline
\end{tabular}

\subsection{Systemic Administration of Stem Cells}

Intravenous delivery of MSCs is the most common approach. Stem cells enter the circular system to secrete trophic factors, however a few of the cells can home to the injured site or wound tissue. Repeated intravenous administration of ADSCs reduced diabetic kidney damage in rats even at the progressive stage, and promote podocyte recovery via secretion of glial cell line-derived neurotrophic factor [103]. However, graft cells may be limited by donor cell entrapment in the lungs or destroyed in the spleen, lymph nodes, or liver after intravenous injection, which reduces the lifespan of the grafted cells after intravenous administration. 
Intra-ventricular injection via interventional technology, although more invasive, is a more efficient method of stem cell delivery to the target sites. In rodent models, $<1 \%$ of intravenously delivered implanted cells arrived at the target organ, compared to $10 \%$ of cells via intra-ventricular injection [100].

Intra-arterial injection significantly reduces trapping of cells in the lungs and increases the likelihood that injected cells reach the target organs in a large animal. Highly-selected intra-arterial injection can prevent the implanted cells widely distributed in other organ [104]. Intra-arterial injection of stem cells into organs had better effects than intravenous injection for tissue regeneration. In a rodent model, cell number and speed of implantation are critical factors to achieve the efficiency of cell therapy. About $1 \times 10^{5}$ MSCs administered through the renal artery homogeneously distributed within the renal tissues, which significantly improved renal function and histological structure, compared to intravenous infusion of MSCs in a rat model of acute kidney injury [104].

In cancer treatment, intra-peritoneal administration is often used to deliver stem cells in vivo, and it can be used to implant stem cells or proteins from their culture in experimental cell therapy approaches. For example, in a rat model of vaginal distention injury, a single intra-peritoneal injection of concentrated media conditioned by MSCs improved urethral sphincter function via increasing leak point pressure 3 weeks after injury [105]. Although intra-peritoneal injection is simple, stem cells may inadvertently be injected into intestine [106]. Intravenous administration of MSCs was superior to intra-peritoneal therapy in reducing colon inflammation in a murine model of colitis [101]. This is because cell migratory capacity and activation of immunosuppressive properties of MSCs transplanted intravenously may more efficiently enhance immunomodulatory effects and tissue repair.

\subsection{Local Administration of Stem Cells}

Local administration is the most efficient route for cell homing and immediate generation of local action via in situ injection or intra-organ infusion to the damaged tissue. Direct injections of stem cells have been reported to use to repair injury in solid organs and their related tissues, such as heart, brain, spinal tissue, liver, kidney, testis, penile cavernous tissue, urethral sphincter, and skeletal muscle. For example, myocardial injection of MSCs for tissue regeneration has been combined with cytokine enhancement in the border zone to create a beneficial microenvironment for cell survival [107]. In a rodent model of streptozotocin-induced diabetes, BMSCs [108] or USCs [61] significantly enhanced endothelial regeneration, increased intracavernous pressure, and restored erectile function. Furthermore, direct injection of stem cells into the testis allows implanted stem cells to penetrate through the blood-testis barrier, improving treatment for infertility [109]. Compared to intravenous injection, intramuscular injection of BMSCs with small gap neurorrhaphy better promoted peripheral nerve regeneration and improved recovery of nerve function in a rat model of peripheral nerve injury [110]. However, in situ administration can be overly traumatic, and its invasiveness often causes massive bleeding and secondary damage.

Collectively, each approach to cell delivery has its own advantages and limitations, so the route of cell delivery should depend on the study's goals, size of the target organ, and animal models to be used.

\section{Optimal Timing for Cell Therapy}

The optimal time to administer stem cell therapy is unclear and likely varies among conditions. Three phases have been identified in the tissue or organ healing process: i.e., injury phase (hours), repair phase (days), and remodeling phase (weeks) [111]. In a model of myocardial infarction, impaired survival of transplanted cells during the acute injury phase due to the cytotoxic environment suggests that the early inflammatory process impairs biological and functional behaviors of engrafted cells [112]. In a subsequent study, the optimal time frame for cell therapy was 4 to 7 days after acute myocardial infarction [113], indicating that the repair phase may be a more favorable time for stem cell implantation. 
In studies of enhancing skeletal muscle repair in a mouse model, intramuscular injection of stem cells 4 days post-injure[114] achieved the most favorable outcomes by increasing angiogenesis and decreasing scar tissue formation after skeletal muscle contusion [115]. Intrastriatal injections 3 days after ischemic injury yielded the highest cell engraftment, vs. injections administration at $6 \mathrm{~h}, 24 \mathrm{~h}, 7$ and 17 days. In addition, MSCs injected 10-15 min after BSMC transplantation caused graft-versus-host disease occurred, but were successful injected 3 and 7 days after BMSC transplantation [116]. The primary effect occurs via trophic effects rather than cell differentiation and replacement, transplantation during the repair and remodeling phases.

\section{Optimal Number of Cells for Injection}

Delivery of appropriate number of stem cells is a pivotal factor in tissue regeneration. The optimal cell concentration for transplantation varies with different organs, tissues, and animal species. Transplanting large numbers of cells intravenously in a single treatment might not achieve a better outcome because the injected cells cause blockages in the capillaries of the lungs. In addition, injection of cells $\left(>1 \times 10^{6} / \mathrm{mL}\right)$ into an artery of a specific organ, such as the renal artery, causes cell breakdown in the glomerular capillaries [117].

In various clinical trials, the effectiveness of cell-based therapy for tissue injury depends on optimal dose of stem cell administration. In patients with steroid-refractory acute graft-versus-host disease, neither high $\left(8 \times 10^{6} \mathrm{MSCs} / \mathrm{kg}\right)$ or low $\left(2 \times 10^{6} \mathrm{MSCs} / \mathrm{kg}\right)$ doses of cells showed significant differences in response rate or primary disease effects [118]. For patients with spinal injury, the effective dose ranges from $0.5 \times 10^{6}$ to $5 \times 10^{6} \mathrm{MSCs} / \mathrm{kg}$ body weight of the recipient [119]. Cell dose ranged from $1 \times 10^{2}$ cells $/ \mathrm{kg}$ up to $2.4 \times 10^{9}$ cells in transplantation of bone marrow mononuclear cells for cardiac applications, underwent different enriching techniques such as manual processing via Ficoll gradient $v s$. automated enrichment for MNCs via Sepax and also distinct vehicles for infusion, highlighting at least some source of variability in clinical outcomes [120]. In addition, repeated infusion of MSCs at certain intervals seems to influence the outcome $[115,120]$. Thus, MSC treatment may be best administered as one-time injection for acute injuries and as multiple injections for chronic diseases.

\section{Rodents vs. Larger Animal Models}

Autologous, allogeneic, and even xenogenous MSCs have achieved therapeutic outcomes after transplanted into rodent hosts. Human ADSCs as grafted cells significantly improved different tissue or organ function and histological structures in immunocompetent rats of a serial of diseases without immunosuppressants [121]. Implanted human bone marrow CD34- ${ }^{-}$cells survived and differentiated up to 42 days in a rat model of intervertebral disc degeneration [122]. Immunocompromised rodents are often used to test the therapeutic effects of human stem cells as xenogenous cells, using tracking approaches, such as green (GFP) or red (mCherry) fluorescent protein. Without previous labeling, human MSCs can be tracked by quantitative PCR (qPCR) of human Alu sequences (300 bp) or histology after labeling of human-specific antigens. These human Alu sequences are highly repeated and species-specific.

Large animal models (e.g., pig, sheep, dog, and nonhuman primates) have many similarities to humans in organ size, anatomy, physiology, metabolic status, and disease occurrence mechanism with humans. However, the cost, specialized facilities, regulatory burden, and ethical issues associated with primate models make alternative large animal models such pigs and sheep more attractive. Pigs are commonly for kidney, bladder, and ureteral tissue regeneration experiments [123]. Research on porcine iPSCs in regenerative medicine has made great progress. For example, pig iPSCs directly injected into ischemic myocardium significantly improved left ventricular function and perfusion [124] (see Table 4). 
Table 4. Benefits and disadvantages of animal models for stem cell therapy.

\begin{tabular}{|c|c|c|}
\hline Comparison Items & Small Animals & Large Animals \\
\hline $\begin{array}{l}\text { Commonly used } \\
\text { animals [125] }\end{array}$ & Mouse, rat, rabbit & Dog, pig, nonhuman primates \\
\hline $\begin{array}{l}\text { Commonly used } \\
\text { cell sources }\end{array}$ & Xenogenous or allogeneic stem cells & Autologous stem cells \\
\hline Optimal cell doses & 0.5-2 millions/injection & 1-5 millions/injection \\
\hline $\begin{array}{l}\text { Route of cell } \\
\text { administration }\end{array}$ & Intravenous, intraperitoneal, intra-organ & $\begin{array}{l}\text { Intra-arterial, intraperitoneal, } \\
\text { intravenous, intra-organ }\end{array}$ \\
\hline Advantages & $\begin{array}{l}\text { Immunocompromised rodents (i.e., NOD/SCID mice, } \\
\text { or NOD-Rag mice) used to test human cells; Rapid tissue } \\
\text { repair process; Used for proof-of-concept studies [125] }\end{array}$ & $\begin{array}{c}\text { Most organs are similar in anatomy } \\
\text { and physiology to humans; Used for } \\
\text { pre-clinical studies [126] }\end{array}$ \\
\hline $\begin{array}{c}\text { Disadvantages } \\
{[125,126]}\end{array}$ & $\begin{array}{l}\text { Not optimal for ureteral, bladder, or urethral } \\
\text { reconstruction }\end{array}$ & $\begin{array}{l}\text { Ethical issues in using some models } \\
\text { More expensive for maintaining }\end{array}$ \\
\hline
\end{tabular}

\section{Future Directions}

Adult stem cells can differentiate into multiple lineages, secrete vital factors related to proliferation and immune regulation, and home to injured sites. While such cell-based therapies are highly promising, challenges remain. More studies are needed to determine the mechanisms and biological properties of stem cells from different sources to enhance their therapeutic efficacy, and ensure safety of using stem cells in humans. In addition, it is pivotal to select the optimal routes of cell administration, timing, cell number for injection, cell sources and passages, to improve cell secretion and immune regulation, which are associated to cell survival, longevity, and overall function. Eventually, stem cell therapy likely will become a means of treating many diseases that currently lack effective treatment.

Acknowledgments: The authors acknowledge funding support from NIH grant R56 DK100669 (Yuanyuan Zhang), National Natural Science Foundation of China (No. 81371704, 81570981, 81570650) and the Basic Research Program of Frontier \& Application Sponsored by Chongqing Science \& Technology Commission (cstc2014jcyjA10039).

Author Contributions: Shan Liu wrote the manuscript and participated in the sequence alignment. Jingli Zhou wrote the manuscript and participated in the sequence alignment. Xuan Zhang helped to write the manuscript. Yang Liu helped to wrote the manuscript. Jin Chen helped to write the manuscript. Bo Hu performed the graphs manufacture. Yuanyuan Zhang conceived and designed the review, participated in the sequence alignment and revised the manuscript, gave the final approval of the version. Jinlin Song conceived and designed the review, agreed to be accountable for all aspects of the work. All authors read and approved the final manuscript.

Conflicts of Interest: The authors declare no conflict of interest.

\section{References}

1. Nauta, A.J.; Fibbe, W.E. Immunomodulatory properties of mesenchymal stromal cells. Blood 2007, 110, 3499-3506. [CrossRef] [PubMed]

2. Trounson, A.; Thakar, R.G.; Lomax, G.; Gibbons, D. Clinical trials for stem cell therapies. BMC Med. 2011, 9, 52. [CrossRef] [PubMed]

3. Lv, F.J.; Tuan, R.S.; Cheung, K.M.; Leung, V.Y. Concise review: The surface markers and identity of human mesenchymal stem cells. Stem Cells 2014, 32, 1408-1419. [CrossRef] [PubMed]

4. Gao, Y.; Jacot, J.G. Stem cells and progenitor cells for tissue-engineered solutions to congenital heart defects. Biomark. Insights 2015, 10, 139-146. [PubMed]

5. Fauza, D.O. Tissue engineering in congenital diaphragmatic hernia. Semin. Pediatr. Surg. 2014, 23, $135-140$. [CrossRef] [PubMed]

6. Wang, A.; Brown, E.G.; Lankford, L.; Keller, B.A.; Pivetti, C.D.; Sitkin, N.A.; Beattie, M.S.; Bresnahan, J.C.; Farmer, D.L. Placental mesenchymal stromal cells rescue ambulation in ovine myelomeningocele. Stem Cells Trans. Med. 2015, 4, 659-669. [CrossRef] [PubMed] 
7. Guijarro, D.; Lebrin, M.; Lairez, O.; Bourin, P.; Piriou, N.; Pozzo, J.; Lande, G.; Berry, M.; le Tourneau, T.; Cussac, D.; et al. Intramyocardial transplantation of mesenchymal stromal cells for chronic myocardial ischemia and impaired left ventricular function: Results of the MESAMI 1 pilot trial. Int. J. Cardiol. 2016, 209, 258-265. [CrossRef] [PubMed]

8. Dasari, V.R.; Veeravalli, K.K.; Dinh, D.H. Mesenchymal stem cells in the treatment of spinal cord injuries: A review. World J. Stem Cells 2014, 6, 120-133. [CrossRef] [PubMed]

9. Jiang, M.H.; Li, G.; Liu, J.; Liu, L.; Wu, B.; Huang, W.; He, W.; Deng, C.; Wang, D.; Li, C.; et al. Nestin ${ }^{+}$ kidney resident mesenchymal stem cells for the treatment of acute kidney ischemia injury. Biomaterials 2015, 50, 56-66. [CrossRef] [PubMed]

10. Thakkar, U.G.; Trivedi, H.L.; Vanikar, A.V.; Dave, S.D. Insulin-secreting adipose-derived mesenchymal stromal cells with bone marrow-derived hematopoietic stem cells from autologous and allogenic sources for type 1 diabetes mellitus. Cytotherapy 2015, 17, 940-947. [CrossRef] [PubMed]

11. De Bari, C. Are mesenchymal stem cells in rheumatoid arthritis the good or bad guys? Arthritis Res. Ther. 2015, 17, 113. [CrossRef] [PubMed]

12. Gharibi, T.; Ahmadi, M.; Seyfizadeh, N.; Jadidi-Niaragh, F.; Yousefi, M. Immunomodulatory characteristics of mesenchymal stem cells and their role in the treatment of multiple sclerosis. Cell. Immunol. 2015, 293, 113-121. [CrossRef] [PubMed]

13. Marfia, G.; Campanella, R.; Navone, S.E.; Zucca, I.; Scotti, A.; Figini, M.; di Vito, C.; Alessandri, G.; Riboni, L.; Parati, E. Potential use of human adipose mesenchymal stromal cells for intervertebral disc regeneration: A preliminary study on biglycan-deficient murine model of chronic disc degeneration. Arthritis Res. Ther. 2014, 16, 457. [CrossRef] [PubMed]

14. Parmar, N.; Ahmadi, R.; Day, R.M. A novel method for differentiation of human mesenchymal stem cells into smooth muscle-like cells on clinically deliverable thermally induced phase separation microspheres. Tissue Eng. Part C Methods 2015, 21, 404-412. [CrossRef] [PubMed]

15. Choi, M.Y.; Yeo, S.W.; Park, K.H. Hearing restoration in a deaf animal model with intravenous transplantation of mesenchymal stem cells derived from human umbilical cord blood. Biochem. Biophys. Res. Commun. 2012, 427, 629-636. [CrossRef] [PubMed]

16. Crisan, M.; Yap, S.; Casteilla, L.; Chen, C.W.; Corselli, M.; Park, T.S.; Andriolo, G.; Sun, B.; Zheng, B.; Zhang, L.; et al. A perivascular origin for mesenchymal stem cells in multiple human organs. Cell Stem Cell 2008, 3, 301-313. [CrossRef] [PubMed]

17. Wexler, S.A.; Donaldson, C.; Denning-Kendall, P.; Rice, C.; Bradley, B.; Hows, J.M. Adult bone marrow is a rich source of human mesenchymal 'stem' cells but umbilical cord and mobilized adult blood are not. Br. J. Haematol. 2003, 121, 368-374. [CrossRef] [PubMed]

18. Zuk, P.A.; Zhu, M.; de Ugarte, D.A.; Huang, J.I.; Mizuno, H.; Alfonso, Z.C.; Fraser, J.K.; Benhaim, P.; Hedrick, M.H. Human adipose tissue is a source of multipotent stem cells. Mol. Biol. Cell 2002, 13, 4279-4295. [CrossRef] [PubMed]

19. Pierdomenico, L.; Calvitti, M.; Rondelli, D.; Arpinati, M.; Chirumbolo, G.; Becchetti, E.; Marchionni, C.; Alviano, F.; Fossati, V.; Staffolani, N.; et al. Multipotent mesenchymal stem cells with immunosuppressive activity can be easily isolated from dental pulp. Transplantation 2005, 80, 836-842. [CrossRef] [PubMed]

20. Murata, D.; Miyakoshi, D.; Hatazoe, T.; Miura, N.; Tokunaga, S.; Fujiki, M.; Nakayama, K.; Misumi, K. Multipotency of equine mesenchymal stem cells derived from synovial fluid. Vet. J. 2014, 202, 53-61. [CrossRef] [PubMed]

21. Nomura, Y.; Ishikawa, M.; Yashiro, Y.; Sanggarnjanavanich, S.; Yamaguchi, T.; Arai, C.; Noda, K.; Takano, Y.; Nakamura, Y.; Hanada, N. Human periodontal ligament fibroblasts are the optimal cell source for induced pluripotent stem cells. Histochem. Cell Biol. 2012, 137, 719-732. [CrossRef] [PubMed]

22. Wang, Y.; Liu, J.; Tan, X.; Li, G.; Gao, Y.; Liu, X.; Zhang, L.; Li, Y. Induced pluripotent stem cells from human hair follicle mesenchymal stem cells. Stem Cell Rev. 2013, 9, 451-560. [CrossRef] [PubMed]

23. Mutlu, L.; Hufnagel, D.; Taylor, H.S. The endometrium as a source of mesenchymal stem cells for regenerative medicine. Biol. Reprod. 2015, 92, 138. [CrossRef] [PubMed]

24. Hu, C.; Cao, H.; Pan, X.; Li, J.; He, J.; Pan, Q.; Xin, J.; Yu, X.; Wang, Y.; Zhu, D.; et al. Adipogenic placenta-derived mesenchymal stem cells are not lineage restricted by withdrawing extrinsic factors: Developing a novel visual angle in stem cell biology. Cell Death Dis. 2016, 7, e2141. [CrossRef] [PubMed] 
25. Capelli, C.; Gotti, E.; Morigi, M.; Rota, C.; Weng, L.; Dazzi, F.; Spinelli, O.; Cazzaniga, G.; Trezzi, R.; Gianatti, A.; et al. Minimally manipulated whole human umbilical cord is a rich source of clinical-grade human mesenchymal stromal cells expanded in human platelet lysate. Cytotherapy 2011, 13, 786-801. [CrossRef] [PubMed]

26. Koerner, J.; Nesic, D.; Romero, J.D.; Brehm, W.; Mainil-Varlet, P.; Grogan, S.P. Equine peripheral blood-derived progenitors in comparison to bone marrow-derived mesenchymal stem cells. Stem Cells 2006, 24, 1613-1619. [CrossRef] [PubMed]

27. Liu, S.S.; Zhang, C.; Zhang, X.; Chen, X.H. Human umbilical cord blood-derived stromal cells: A new source of stromal cells in hematopoietic stem cell transplantation. Crit. Rev. Oncol. Hematol. 2014, 90, 93-98. [CrossRef] [PubMed]

28. Schmidt, D.; Achermann, J.; Odermatt, B.; Genoni, M.; Zund, G.; Hoerstrup, S.P. Cryopreserved amniotic fluid-derived cells: A lifelong autologous fetal stem cell source for heart valve tissue engineering. J. Heart Valve Dis. 2008, 17, 446-455. [PubMed]

29. Mehrabani, D.P.; Nazarabadi, R.B.M.; Kasraeian, M.M.; Tamadon, A.P.; Dianatpour, M.P.; Vahdati, A.P.; Zare, S.B.; Ghobadi, F.D. Growth kinetics, characterization, and plasticity of human menstrual blood stem cells. Iran. J. Med. Sci. 2016, 41, 132-139. [PubMed]

30. Hassiotou, F.; Beltran, A.; Chetwynd, E.; Stuebe, A.M.; Twigger, A.J.; Metzger, P.; Trengove, N.; Lai, C.T.; Filgueira, L.; Blancafort, P.; et al. Breastmilk is a novel source of stem cells with multilineage differentiation potential. Stem Cells 2012, 30, 2164-2174. [CrossRef] [PubMed]

31. Zhang, Y.; McNeill, E.; Tian, H.; Soker, S.; Andersson, K.E.; Yoo, J.J.; Atala, A. Urine derived cells are a potential source for urological tissue reconstruction. J. Urol. 2008, 180, 2226-2233. [CrossRef] [PubMed]

32. Alvarez, R.; Lee, H.L.; Wang, C.Y.; Hong, C. Characterization of the osteogenic potential of mesenchymal stem cells from human periodontal ligament based on cell surface markers. Int. J. Oral. Sci. 2015, 7, 213-219. [CrossRef] [PubMed]

33. Luzzani, C.; Neiman, G.; Garate, X.; Questa, M.; Solari, C.; Fernandez Espinosa, D.; Garcia, M.; Errecalde, A.L.; Guberman, A.; Scassa, M.E.; et al. A therapy-grade protocol for differentiation of pluripotent stem cells into mesenchymal stem cells using platelet lysate as supplement. Stem Cell Res. Ther. 2015, 6, 6. [CrossRef] [PubMed]

34. Maleki, M.; Ghanbarvand, F.; Reza Behvarz, M.; Ejtemaei, M.; Ghadirkhomi, E. Comparison of mesenchymal stem cell markers in multiple human adult stem cells. Int. J. Stem Cells 2014, 7, 118-126. [CrossRef] [PubMed]

35. Mohanty, N.; Gulati, B.R.; Kumar, R.; Gera, S.; Kumar, P.; Somasundaram, R.K.; Kumar, S. Immunophenotypic characterization and tenogenic differentiation of mesenchymal stromal cells isolated from equine umbilical cord blood. Vitro Cell. Dev. Biol. Anim. 2014, 50, 538-548. [CrossRef] [PubMed]

36. Mohanty, N.; Gulati, B.R.; Kumar, R.; Gera, S.; Kumar, S.; Kumar, P.; Yadav, P.S. Phenotypical and functional characteristics of mesenchymal stem cells derived from equine umbilical cord blood. Cytotechnology 2014, 12, 1-13. [CrossRef] [PubMed]

37. Trivedi, P.; Hematti, P. Derivation and immunological characterization of mesenchymal stromal cells from human embryonic stem cells. Exp. Hematol. 2008, 36, 350-359. [CrossRef] [PubMed]

38. Wang, X.; Liu, Y.; Zhou, K.; Zhang, G.; Wang, F.; Ren, J. Isolation and characterization of $\operatorname{cd} 105^{+} / \mathrm{cd}^{2} 0^{+}$ subpopulation in breast cancer MDA-MB-231 cell line. Int. J. Clin. Exp. Pathol. 2015, 8, 5105-5112. [PubMed]

39. Szala, S.; Wisniewska, E.; Czapla, J. [mesenchymal stromal cells]. Postepy Hig. Med. Dosw. (Online) 2014, 68, 1287-1298. [CrossRef]

40. Miranda, H.C.; Herai, R.H.; Thome, C.H.; Gomes, G.G.; Panepucci, R.A.; Orellana, M.D.; Covas, D.T.; Muotri, A.R.; Greene, L.J.; Faca, V.M. A quantitative proteomic and transcriptomic comparison of human mesenchymal stem cells from bone marrow and umbilical cord vein. Proteomics 2012, 12, 2607-2617. [CrossRef] [PubMed]

41. Wegmeyer, H.; Broske, A.M.; Leddin, M.; Kuentzer, K.; Nisslbeck, A.K.; Hupfeld, J.; Wiechmann, K.; Kuhlen, J.; von Schwerin, C.; Stein, C.; et al. Mesenchymal stromal cell characteristics vary depending on their origin. Stem Cells Dev. 2013, 22, 2606-2618. [CrossRef] [PubMed]

42. Sorensen, A.L.; Timoskainen, S.; West, F.D.; Vekterud, K.; Boquest, A.C.; Ahrlund-Richter, L.; Stice, S.L.; Collas, P. Lineage-specific promoter DNA methylation patterns segregate adult progenitor cell types. Stem Cells Dev. 2010, 19, 1257-1266. [CrossRef] [PubMed] 
43. Pizzute, T.; Lynch, K.; Pei, M. Impact of tissue-specific stem cells on lineage-specific differentiation: A focus on the musculoskeletal system. Stem Cell Rev. 2015, 11, 119-132. [CrossRef] [PubMed]

44. Xie, L.; Zhang, N.; Marsano, A.; Vunjak-Novakovic, G.; Zhang, Y.; Lopez, M.J. In vitro mesenchymal trilineage differentiation and extracellular matrix production by adipose and bone marrow derived adult equine multipotent stromal cells on a collagen scaffold. Stem Cell Rev. 2013, 9, 858-872. [CrossRef] [PubMed]

45. Xu, Y.; Zhang, X.J.; Fang, L.; Zhao, T.B. Co-culture of annulus fibrosus cells and bone marrow mesenchymal stem cells. GMR 2015, 14, 3932-3938. [CrossRef] [PubMed]

46. Strassburg, S.; Nienhueser, H.; Bjorn Stark, G.; Finkenzeller, G.; Torio-Padron, N. Co-culture of adipose-derived stem cells and endothelial cells in fibrin induces angiogenesis and vasculogenesis in a chorioallantoic membrane model. J. Tissue Eng. Regen. Med. 2013. [CrossRef] [PubMed]

47. Pan, C.; Kumar, C.; Bohl, S.; Klingmueller, U.; Mann, M. Comparative proteomic phenotyping of cell lines and primary cells to assess preservation of cell type-specific functions. MCP 2009, 8, 443-450. [CrossRef] [PubMed]

48. Oliveira, P.H.; Boura, J.S.; Abecasis, M.M.; Gimble, J.M.; da Silva, C.L.; Cabral, J.M. Impact of hypoxia and long-term cultivation on the genomic stability and mitochondrial performance of ex vivo expanded human stem/stromal cells. Stem Cell Res. 2012, 9, 225-236. [CrossRef] [PubMed]

49. Choi, J.S.; Lee, B.J.; Park, H.Y.; Song, J.S.; Shin, S.C.; Lee, J.C.; Wang, S.G.; Jung, J.S. Effects of donor age, long-term passage culture, and cryopreservation on tonsil-derived mesenchymal stem cells. Cell. Physiol. Biochem. 2015, 36, 85-99. [CrossRef] [PubMed]

50. Khoo, M.L.; Shen, B.; Tao, H.; Ma, D.D. Long-term serial passage and neuronal differentiation capability of human bone marrow mesenchymal stem cells. Stem Cells Dev. 2008, 17, 883-896. [CrossRef] [PubMed]

51. Tan, A.R.; Alegre-Aguaron, E.; O’Connell, G.D.; VandenBerg, C.D.; Aaron, R.K.; Vunjak-Novakovic, G.; Chloe Bulinski, J.; Ateshian, G.A.; Hung, C.T. Passage-dependent relationship between mesenchymal stem cell mobilization and chondrogenic potential. Osteoarthr. Cartil. 2015, 23, 319-327. [CrossRef] [PubMed]

52. Wagner, W.; Bork, S.; Horn, P.; Krunic, D.; Walenda, T.; Diehlmann, A.; Benes, V.; Blake, J.; Huber, F.X.; Eckstein, V.; et al. Aging and replicative senescence have related effects on human stem and progenitor cells. PLoS ONE 2009, 4, e5846. [CrossRef] [PubMed]

53. Sureshkumar, P.; Srinivasan, S.P.; Natarajan, K.; Gaspar, J.A.; Hescheler, J.; Sachinidis, A. Stem cells and differentiation-A synoptic review of patents granted since 2009. Exp. Opin. Ther. Pat. 2015, 25, 663-673. [CrossRef] [PubMed]

54. Takahashi, K.; Yamanaka, S. Induction of pluripotent stem cells from mouse embryonic and adult fibroblast cultures by defined factors. Cell 2006, 126, 663-676. [CrossRef] [PubMed]

55. Singh, V.K.; Kalsan, M.; Kumar, N.; Saini, A.; Chandra, R. Induced pluripotent stem cells: Applications in regenerative medicine, disease modeling, and drug discovery. Front. Cell Dev. Biol. 2015, 3, 2. [CrossRef] [PubMed]

56. Cefalo, M.G.; Carai, A.; Miele, E.; Po, A.; Ferretti, E.; Mastronuzzi, A.; Germano, I.M. Human iPSC for therapeutic approaches to the nervous system: Present and future applications. Stem Cells Int. 2016, 2016, 4869071. [CrossRef] [PubMed]

57. Hacein-Bey-Abina, S.; von Kalle, C.; Schmidt, M.; le Deist, F.; Wulffraat, N.; McIntyre, E.; Radford, I.; Villeval, J.L.; Fraser, C.C.; Cavazzana-Calvo, M.; et al. A serious adverse event after successful gene therapy for X-linked severe combined immunodeficiency. N. Engl. J. Med. 2003, 348, 255-256. [CrossRef] [PubMed]

58. Lehrman, S. Virus treatment questioned after gene therapy death. Nature 1999, 401, 517-518. [CrossRef] [PubMed]

59. Taha, M.F. Cell based-gene delivery approaches for the treatment of spinal cord injury and neurodegenerative disorders. Curr. Stem Cell Res. Ther. 2010, 5, 23-36. [CrossRef] [PubMed]

60. Jabbarzadeh, E.; Starnes, T.; Khan, Y.M.; Jiang, T.; Wirtel, A.J.; Deng, M.; Lv, Q.; Nair, L.S.; Doty, S.B.; Laurencin, C.T. Induction of angiogenesis in tissue-engineered scaffolds designed for bone repair: A combined gene therapy-cell transplantation approach. Proc. Natl. Acad. Sci. USA 2008, 105, 11099-11104. [CrossRef] [PubMed]

61. Ouyang, B.; Sun, X.; Han, D.; Chen, S.; Yao, B.; Gao, Y.; Bian, J.; Huang, Y.; Zhang, Y.; Wan, Z.; et al. Human urine-derived stem cells alone or genetically-modified with FGF2 improve type 2 diabetic erectile dysfunction in a rat model. PLoS ONE 2014, 9, e92825. [CrossRef] [PubMed] 
62. Yang, J.; Jiang, Z.; Fitzgerald, D.C.; Ma, C.; Yu, S.; Li, H.; Zhao, Z.; Li, Y.; Ciric, B.; Curtis, M.; et al. Adult neural stem cells expressing IL-10 confer potent immunomodulation and remyelination in experimental autoimmune encephalitis. J. Clin. Investig. 2009, 119, 3678-3691. [CrossRef] [PubMed]

63. Li, Y.; Tew, S.R.; Russell, A.M.; Gonzalez, K.R.; Hardingham, T.E.; Hawkins, R.E. Transduction of passaged human articular chondrocytes with adenoviral, retroviral, and lentiviral vectors and the effects of enhanced expression of SOX9. Tissue Eng. 2004, 10, 575-584. [CrossRef] [PubMed]

64. Mark Saltzman, W.; Baldwin, S.P. Materials for protein delivery in tissue engineering. Adv. Drug Deliv. Rev. 1998, 33, 71-86. [PubMed]

65. Sukarto, A.; Yu, C.; Flynn, L.E.; Amsden, B.G. Co-delivery of adipose-derived stem cells and growth factor-loaded microspheres in RGD-grafted $N$-methacrylate glycol chitosan gels for focal chondral repair. Biomacromolecules 2012, 13, 2490-2502. [CrossRef] [PubMed]

66. Kang, S.W.; Jeon, O.; Kim, B.S. Poly(lactic-co-glycolic acid) microspheres as an injectable scaffold for cartilage tissue engineering. Tissue Eng. 2005, 11, 438-447. [CrossRef] [PubMed]

67. Eswaramoorthy, R.; Chang, C.C.; Wu, S.C.; Wang, G.J.; Chang, J.K.; Ho, M.L. Sustained release of PTH(1-34) from PLGA microspheres suppresses osteoarthritis progression in rats. Acta Biomater. 2012, 8, 2254-2262. [CrossRef] [PubMed]

68. Niu, X.; Feng, Q.; Wang, M.; Guo, X.; Zheng, Q. Porous nano-HA/collagen/PLLA scaffold containing chitosan microspheres for controlled delivery of synthetic peptide derived from BMP-2. J. Control. Release 2009, 134, 111-117. [CrossRef] [PubMed]

69. Bian, L.; Zhai, D.Y.; Tous, E.; Rai, R.; Mauck, R.L.; Burdick, J.A. Enhanced MSC chondrogenesis following delivery of TGF- $\beta 3$ from alginate microspheres within hyaluronic acid hydrogels in vitro and in vivo. Biomaterials 2011, 32, 6425-6434. [CrossRef] [PubMed]

70. Wang, Y.; Wei, Y.T.; Zu, Z.H.; Ju, R.K.; Guo, M.Y.; Wang, X.M.; Xu, Q.Y.; Cui, F.Z. Combination of hyaluronic acid hydrogel scaffold and PLGA microspheres for supporting survival of neural stem cells. Pharm. Res. 2011, 28, 1406-1414. [CrossRef] [PubMed]

71. Lim, J.J.; Hammoudi, T.M.; Bratt-Leal, A.M.; Hamilton, S.K.; Kepple, K.L.; Bloodworth, N.C.; McDevitt, T.C.; Temenoff, J.S. Development of nano- and microscale chondroitin sulfate particles for controlled growth factor delivery. Acta Biomater. 2011, 7, 986-995. [CrossRef] [PubMed]

72. Zhao, W.; Zhang, C.; Jin, C.; Zhang, Z.; Kong, D.; Xu, W.; Xiu, Y. Periurethral injection of autologous adipose-derived stem cells with controlled-release nerve growth factor for the treatment of stress urinary incontinence in a rat model. Eur. Urol. 2011, 59, 155-163. [CrossRef] [PubMed]

73. Olson, A.; Graver, A.; Grande, D. Scaffolds for articular cartilage repair. J. Long Term Eff. Med. Implant. 2012, 22, 219-227. [CrossRef]

74. Nie, T.; Baldwin, A.; Yamaguchi, N.; Kiick, K.L. Production of heparin-functionalized hydrogels for the development of responsive and controlled growth factor delivery systems. J. Control. Release 2007, 122, 287-296. [CrossRef] [PubMed]

75. Skop, N.B.; Calderon, F.; Levison, S.W.; Gandhi, C.D.; Cho, C.H. Heparin crosslinked chitosan microspheres for the delivery of neural stem cells and growth factors for central nervous system repair. Acta Biomater. 2013, 9, 6834-6843. [CrossRef] [PubMed]

76. Webber, M.J.; Han, X.; Murthy, S.N.; Rajangam, K.; Stupp, S.I.; Lomasney, J.W. Capturing the stem cell paracrine effect using heparin-presenting nanofibres to treat cardiovascular diseases. J. Tissue Eng. Regen. Med. 2010, 4, 600-610. [CrossRef] [PubMed]

77. Jung, H.H.; Park, K.; Han, D.K. Preparation of TGF- $\beta 1$-conjugated biodegradable pluronic F127 hydrogel and its application with adipose-derived stem cells. J. Control. Release 2010, 147, 84-91. [CrossRef] [PubMed]

78. Yu, S.P.; Wei, Z.; Wei, L. Preconditioning strategy in stem cell transplantation therapy. Trans. Stroke Res. 2013, 4, 76-88. [CrossRef] [PubMed]

79. Chang, W.; Song, B.W.; Moon, J.Y.; Cha, M.J.; Ham, O.; Lee, S.Y.; Choi, E.; Hwang, K.C. Anti-death strategies against oxidative stress in grafted mesenchymal stem cells. Histol. Histopathol. 2013, 28, 1529-1536. [PubMed]

80. Lo, E.H.; Wang, X.; Cuzner, M.L. Extracellular proteolysis in brain injury and inflammation: Role for plasminogen activators and matrix metalloproteinases. J. Neurosci. Res. 2002, 69, 1-9. [CrossRef] [PubMed]

81. Sart, S.; Ma, T.; Li, Y. Preconditioning stem cells for in vivo delivery. BioRes. Open Access 2014, 3, 137-149. [CrossRef] [PubMed] 
82. Boyette, L.B.; Creasey, O.A.; Guzik, L.; Lozito, T.; Tuan, R.S. Human bone marrow-derived mesenchymal stem cells display enhanced clonogenicity but impaired differentiation with hypoxic preconditioning. Stem Cells Trans. Med. 2014, 3, 241-254. [CrossRef] [PubMed]

83. Wei, L.; Fraser, J.L.; Lu, Z.Y.; Hu, X.; Yu, S.P. Transplantation of hypoxia preconditioned bone marrow mesenchymal stem cells enhances angiogenesis and neurogenesis after cerebral ischemia in rats. Neurobiol. Dis. 2012, 46, 635-645. [CrossRef] [PubMed]

84. Haider, H.; Ashraf, M. Preconditioning and stem cell survival. J. Cardiovasc. Trans. Res. 2010, 3, 89-102. [CrossRef] [PubMed]

85. Rosova, I.; Dao, M.; Capoccia, B.; Link, D.; Nolta, J.A. Hypoxic preconditioning results in increased motility and improved therapeutic potential of human mesenchymal stem cells. Stem Cells 2008, 26, 2173-2182. [CrossRef] [PubMed]

86. Pati, S.; Supeno, N.E.; Muthuraju, S.; Abdul Hadi, R.; Ghani, A.R.; Idris, F.M.; Maletic-Savatic, M.; Abdullah, J.M.; Jaafar, H. MicroRNA profiling reveals unique mirna signatures in IGF-1 treated embryonic striatal stem cell fate decisions in striatal neurogenesis in vitro. BioMed Res. Int. 2014, 2014, 503162. [CrossRef] [PubMed]

87. Lu, G.; Ashraf, M.; Haider, K.H. Insulin-like growth factor-1 preconditioning accentuates intrinsic survival mechanism in stem cells to resist ischemic injury by orchestrating protein kinase C $\alpha$-Erk1/2 activation. Antioxid. Redox Signal. 2012, 16, 217-227. [CrossRef] [PubMed]

88. Xinaris, C.; Morigi, M.; Benedetti, V.; Imberti, B.; Fabricio, A.S.; Squarcina, E.; Benigni, A.; Gagliardini, E.; Remuzzi, G. A novel strategy to enhance mesenchymal stem cell migration capacity and promote tissue repair in an injury specific fashion. Cell Trans. 2013, 22, 423-436. [CrossRef] [PubMed]

89. Ma, H.L.; Chen, T.H.; Low-Tone Ho, L.; Hung, S.C. Neocartilage from human mesenchymal stem cells in alginate: Implied timing of transplantation. J. Biomed. Mater. Res. Part A 2005, 74, 439-446. [CrossRef] [PubMed]

90. Doorn, J.; van de Peppel, J.; van Leeuwen, J.P.; Groen, N.; van Blitterswijk, C.A.; de Boer, J. Pro-osteogenic trophic effects by PKA activation in human mesenchymal stromal cells. Biomaterials 2011, 32, 6089-6098. [CrossRef] [PubMed]

91. Khan, M.; Ali, F.; Mohsin, S.; Akhtar, S.; Mehmood, A.; Choudhery, M.S.; Khan, S.N.; Riazuddin, S. Preconditioning diabetic mesenchymal stem cells with myogenic medium increases their ability to repair diabetic heart. Stem Cell Res. Ther. 2013, 4, 58. [CrossRef] [PubMed]

92. Chacko, S.M.; Ahmed, S.; Selvendiran, K.; Kuppusamy, M.L.; Khan, M.; Kuppusamy, P. Hypoxic preconditioning induces the expression of prosurvival and proangiogenic markers in mesenchymal stem cells. Am. J. Physiol. Cell Physiol. 2010, 299, C1562-C1570. [CrossRef] [PubMed]

93. Lee, C.S.; Watkins, E.; Burnsed, O.A.; Schwartz, Z.; Boyan, B.D. Tailoring adipose stem cell trophic factor production with differentiation medium components to regenerate chondral defects. Tissue Eng. Part A 2013, 19, 1451-1464. [CrossRef] [PubMed]

94. Tratwal, J.; Mathiasen, A.B.; Juhl, M.; Brorsen, S.K.; Kastrup, J.; Ekblond, A. Influence of vascular endothelial growth factor stimulation and serum deprivation on gene activation patterns of human adipose tissue-derived stromal cells. Stem Cell Res. Ther. 2015, 6, 62. [CrossRef] [PubMed]

95. Karp, J.M.; Leng Teo, G.S. Mesenchymal stem cell homing: The devil is in the details. Cell Stem Cell 2009, 4, 206-216. [CrossRef] [PubMed]

96. Fujiwara, H.; Kubota, T.; Amaike, H.; Inada, S.; Takashima, K.; Atsuji, K.; Yoshimura, M.; Maemondo, M.; Narumi, K.; Nukiwa, T.; et al. Suppression of peritoneal implantation of gastric cancer cells by adenovirus vector-mediated NK4 expression. Cancer Gene Ther. 2005, 12, 206-216. [CrossRef] [PubMed]

97. Fu, X.M.; Yamawaki-Ogata, A.; Oshima, H.; Ueda, Y.; Usui, A.; Narita, Y. Intravenous administration of mesenchymal stem cells prevents angiotensin II-induced aortic aneurysm formation in apolipoprotein E-deficient mouse. J. Trans. Med. 2013, 11, 175. [CrossRef] [PubMed]

98. Chan, J.; Waddington, S.N.; O’Donoghue, K.; Kurata, H.; Guillot, P.V.; Gotherstrom, C.; Themis, M.; Morgan, J.E.; Fisk, N.M. Widespread distribution and muscle differentiation of human fetal mesenchymal stem cells after intrauterine transplantation in dystrophic mdx mouse. Stem Cells 2007, 25, 875-884. [CrossRef] [PubMed]

99. Yamaoka, K. [potential of bone regenerative therapy with mesenchymal stem cells in rheumatoid arthritis]. Clin. Calcium 2016, 26, 758-762. [PubMed] 
100. Zhang, L.; Li, K.; Liu, X.; Li, D.; Luo, C.; Fu, B.; Cui, S.; Zhu, F.; Zhao, R.C.; Chen, X. Repeated systemic administration of human adipose-derived stem cells attenuates overt diabetic nephropathy in rats. Stem Cells Dev. 2013. [CrossRef] [PubMed]

101. Goncalves Fda, C.; Schneider, N.; Pinto, F.O.; Meyer, F.S.; Visioli, F.; Pfaffenseller, B.; Lopez, P.L.; Passos, E.P.; Cirne-Lima, E.O.; Meurer, L.; et al. Intravenous vs. intraperitoneal mesenchymal stem cells administration: What is the best route for treating experimental colitis? World J. Gastroenterol. 2014. [CrossRef]

102. Muschler, G.F.; Nakamoto, C.; Griffith, L.G. Engineering principles of clinical cell-based tissue engineering. J. Bone Jt. Surg. Am. 2004, 86, 1541-1558.

103. Rivera, F.J.; Aigner, L. Adult mesenchymal stem cell therapy for myelin repair in multiple sclerosis. Biol. Res. 2012, 45, 257-268. [CrossRef] [PubMed]

104. Mangera, A.; Chapple, C.R. Tissue engineering in urethral reconstruction-An update. Asian J. Androl. 2013, 15, 89-92. [CrossRef] [PubMed]

105. Cai, J.; Yu, X.; Xu, R.; Fang, Y.; Qian, X.; Liu, S.; Teng, J.; Ding, X. Maximum efficacy of mesenchymal stem cells in rat model of renal ischemia-reperfusion injury: Renal artery administration with optimal numbers. PLoS ONE 2014, 9, e92347. [CrossRef] [PubMed]

106. Deng, K.; Lin, D.L.; Hanzlicek, B.; Balog, B.; Penn, M.S.; Kiedrowski, M.J.; Hu, Z.; Ye, Z.; Zhu, H.; Damaser, M.S. Mesenchymal stem cells and their secretome partially restore nerve and urethral function in a dual muscle and nerve injury stress urinary incontinence model. Am. J. Physiol. Ren. Physiol. 2015, 308, F92-F100. [CrossRef] [PubMed]

107. Herrmann, J.L.; Abarbanell, A.M.; Weil, B.R.; Wang, Y.; Poynter, J.A.; Manukyan, M.C.; Meldrum, D.R. Postinfarct intramyocardial injection of mesenchymal stem cells pretreated with TGF- $\alpha$ improves acute myocardial function. Am. J. Physiol. Regul. Integr. Comp. Physiol. 2010, 299, R371-R378. [CrossRef] [PubMed]

108. Sun, C.; Lin, H.; Yu, W.; Li, X.; Chen, Y.; Qiu, X.; Wang, R.; Dai, Y. Neurotrophic effect of bone marrow mesenchymal stem cells for erectile dysfunction in diabetic rats. Int. J. Androl. 2012, 35, 601-607. [CrossRef] [PubMed]

109. Zhang, D.; Liu, X.; Peng, J.; He, D.; Lin, T.; Zhu, J.; Li, X.; Zhang, Y.; Wei, G. Potential spermatogenesis recovery with bone marrow mesenchymal stem cells in an azoospermic rat model. Int. J. Mol. Sci. 2014, 15, 13151-13165. [CrossRef] [PubMed]

110. Wang, P.; Zhang, Y.; Zhao, J.; Jiang, B. Intramuscular injection of bone marrow mesenchymal stem cells with small gap neurorrhaphy for peripheral nerve repair. Neurosci. Lett. 2015, 585, 119-125. [CrossRef] [PubMed]

111. Jarvinen, T.A.; Jarvinen, M.; Kalimo, H. Regeneration of injured skeletal muscle after the injury. Muscles Ligaments Tend. J. 2013, 3, 337-345.

112. Deten, A.; Volz, H.C.; Briest, W.; Zimmer, H.G. Cardiac cytokine expression is upregulated in the acute phase after myocardial infarction. Experimental studies in rats. Cardiovasc. Res. 2002, 55, 329-340. [CrossRef]

113. Hampel, C.; Wienhold, D.; Benken, N.; Eggersmann, C.; Thuroff, J.W. Definition of overactive bladder and epidemiology of urinary incontinence. Urology 1997, 50, 4-14. [CrossRef]

114. Ota, S.; Uehara, K.; Nozaki, M.; Kobayashi, T.; Terada, S.; Tobita, K.; Fu, F.H.; Huard, J. Intramuscular transplantation of muscle-derived stem cells accelerates skeletal muscle healing after contusion injury via enhancement of angiogenesis. Am. J. Sports Med. 2011, 39, 1912-1922. [CrossRef] [PubMed]

115. Le Blanc, K.; Frassoni, F.; Ball, L.; Locatelli, F.; Roelofs, H.; Lewis, I.; Lanino, E.; Sundberg, B.; Bernardo, M.E.; Remberger, M.; et al. Mesenchymal stem cells for treatment of steroid-resistant, severe, acute graft-versus-host disease: A phase ii study. Lancet 2008, 371, 1579-1586. [CrossRef]

116. Dong, J.Y.; Zhang, Y.H.; Qin, L.Q. Erectile dysfunction and risk of cardiovascular disease: Meta-analysis of prospective cohort studies. J. Am. Coll. Cardiol. 2011, 58, 1378-1385. [CrossRef] [PubMed]

117. Van Koppen, A.; Joles, J.A.; Bongartz, L.G.; van den Brandt, J.; Reichardt, H.M.; Goldschmeding, R.; Nguyen, T.Q.; Verhaar, M.C. Healthy bone marrow cells reduce progression of kidney failure better than CKD bone marrow cells in rats with established chronic kidney disease. Cell Transplant. 2012, 21, 2299-2312. [CrossRef] [PubMed]

118. Kebriaei, P.; Isola, L.; Bahceci, E.; Holland, K.; Rowley, S.; McGuirk, J.; Devetten, M.; Jansen, J.; Herzig, R.; Schuster, M.; et al. Adult human mesenchymal stem cells added to corticosteroid therapy for the treatment of acute graft-versus-host disease. Biol. Blood Marrow Transplant. 2009, 15, 804-811. [CrossRef] [PubMed]

119. Sharma, R.R.; Pollock, K.; Hubel, A.; McKenna, D. Mesenchymal stem or stromal cells: A review of clinical applications and manufacturing practices. Transfusion 2014, 54, 1418-1437. [CrossRef] [PubMed] 
120. Behfar, A.; Crespo-Diaz, R.; Terzic, A.; Gersh, B.J. Cell therapy for cardiac repair-Lessons from clinical trials. Nat. Rev. Cardiol. 2014, 11, 232-246. [CrossRef] [PubMed]

121. Lin, C.S.; Lin, G.; Lue, T.F. Allogeneic and xenogeneic transplantation of adipose-derived stem cells in immunocompetent recipients without immunosuppressants. Stem Cells Dev. 2012, 21, 2770-2778. [CrossRef] [PubMed]

122. Wei, A.; Tao, H.; Chung, S.A.; Brisby, H.; Ma, D.D.; Diwan, A.D. The fate of transplanted xenogeneic bone marrow-derived stem cells in rat intervertebral discs. J. Orthop. Res. 2009, 27, 374-379. [CrossRef] [PubMed]

123. Coulthard, M.G.; Flecknell, P.; Orr, H.; Manas, D.; O’Donnell, M. Renal scarring caused by vesicoureteric reflux and urinary infection: A study in pigs. Pediatr. Nephrol. 2002, 17, 481-484. [CrossRef] [PubMed]

124. Li, X.; Zhang, F.; Song, G.; Gu, W.; Chen, M.; Yang, B.; Li, D.; Wang, D.; Cao, K. Intramyocardial injection of pig pluripotent stem cells improves left ventricular function and perfusion: A study in a porcine model of acute myocardial infarction. PLoS ONE 2013, 8, e66688. [CrossRef] [PubMed]

125. Harding, J.; Roberts, R.M.; Mirochnitchenko, O. Large animal models for stem cell therapy. Stem Cell Res. Ther. 2013, 4, 23. [CrossRef] [PubMed]

126. Plews, J.R.; Gu, M.; Longaker, M.T.; Wu, J.C. Large animal induced pluripotent stem cells as pre-clinical models for studying human disease. J. Cell. Mol. Med. 2012, 16, 1196-1202. [CrossRef] [PubMed]

(C) 2016 by the authors; licensee MDPI, Basel, Switzerland. This article is an open access article distributed under the terms and conditions of the Creative Commons Attribution (CC-BY) license (http://creativecommons.org/licenses/by/4.0/). 